\title{
Facts, Figures, and the Politics of Measurement
}

\author{
The Construction and Diffusion of Remittances \\ as a Financial Flow
}

As late as 1998, it was still possible for a well-informed observer to review the extant literature on migrant remittances and conclude: "There is little doubt that this topic interests many, that it has potential for further study, and that remittances can (and do) make important contributions to the development of certain countries. Nonetheless, for the most part, remittances have not received the sustained attention required, either by the recipient governments, international financial institutions, local communities, or by the private sector" (Waller Meyers, 1998).

Within a few short years, this situation had completely changed. Around the turn of the millennium a global consensus was emerging among international institutions, state agencies, civil-society organizations, and private financial-services firms around the valuable contribution that migrants' remittances could make to development in the global South. International institutions of various stripes launched major projects linking the resources and capacities of migrants to their agencies' project portfolios. ${ }^{1}$ At the same time, states on both the sending and 
the receiving end of transnational migration circuits were experimenting with their own policies designed to maximize the developmental impacts of migration. (See Levitt and de la Dehesa, 2003; Østergaard-Nielsen, 20II.) And commercial financial entities increasingly began promoting remittance-transfer services and focusing on improving access to "underserved" migrants and their transnational households.

This chapter focuses on this remarkable resurgence in enthusiasm regarding the developmental potential of migration and remittances. This growing interest in remittances was the direct result of intellectual efforts and political practices undertaken by researchers and policy entrepreneurs working within a handful of international development organizations. The knowledge work of the policy experts within these agencies - as well as their political efforts to get others to adopt their new ways of measuring migrants' remittances-allowed the world to see the potential connection between cross-border migration, the remittances it generates, and development in a new light. While the emphasis of earlier debates about migration and development might have focused significant attention on the potential for migrants themselves to act as agents of change, as individuals and/or collectivities who might themselves put money, knowledge, skills, and political resources acquired abroad into transformative practices back home, the center of gravity now shifted. With attention now squarely, if not exclusively, placed on the possibilities for the monies that migrants transfer across international boundaries to serve as a "development tool," global financial institutions and markets came to be positioned as privileged agents of change.

Generating this new vision of remittances as a development tool and spreading it broadly across the world was a significant accomplishment, one that deserves greater scrutiny. This chapter 
and the next take on this task by examining the governmental work of policy experts who encapsulated and diffused the representation of remittances as a financial flow and delineated a set of market-based policy solutions that promised to leverage migrants' resources for development purposes.

Examining the growing centrality of remittances in discussions about development, this chapter takes seriously the claim that, as one Multilateral Investment Fund (MIF) document put it, the work carried out by MIF officials and their allies to document "the increasing importance of remittances" succeeded in engaging "international organizations, national governments, universities, foundations, and perhaps most importantly, financial institutions... [in] the process of 'discovering remittances'" (MIF, 2003: 3). But rather than simply take this assertion at face value, I dig deeper, asking how the researchers and policy entrepreneurs animating the R-2-D agenda accomplished this task and what it was, exactly, that they helped the world to discover about remittances.

In pursuing this task I take a cue from scholars importing analytic tools from science and technology studies and the governmentality approach into the study of global politics and economics. ${ }^{2}$ (For example, Mitchell, 2002, 2009; Larner and Walters, 2004.) In what follows I focus attention on the knowledge work carried out by the researchers and policy advocates who conjured up, elaborated, and diffused the R-2-D agenda's representation of remittances as a financial flow and an underutilized resource for development. First, I trace out the technical practices that allowed remittances to be seen as a financial flow, with an underlying set of characteristics calling for further integration within global financial markets and institutions as a means to promote (financial) development. This section focuses on the design of graphical depictions of remittances and on efforts to 
improve statistical measurements of their flow across international borders so as to make these financial flows appear as an attractive source of development finance. In the second section I move on to analyze the power-laden processes of policy mobility and transfer that helped spread this representation of remittances as a financial flow from a few centers of discursive and calculative production more broadly across the Americas and around the world.

\section{CALCULATIVE PRACTICES AND VISUAL REPRESENTATIONS OF REMITTANCES \\ AS A FINANCIAL FLOW}

Policy entrepreneurs' efforts at raising consciousness about the importance of remittances for development were complicated by questions about the validity and accuracy of official statistics on these cross-border financial transfers. There was general agreement among the early proponents of the R-2-D agenda that, until at least the early 2000 s, the official statistics produced by national government agencies as part of their balance-ofpayments reporting to the International Monetary Fund (IMF) grossly underestimated the true magnitude of remittances. As one of the leading proponents of the agenda has been fond of saying, "the main organization that tracks international financial flows, the International Monetary Fund, for years literally relegated billions of dollars of remittances to the 'errors and omissions' category of its accounts" (Terry, 2005: 5).

Despite their shared concern about the quality of available data, the various officials, agencies, and experts promoting the $\mathrm{R}-2-\mathrm{D}$ agenda were not in agreement on the best path to remedy this situation. The remittance research coming from within the 
World Bank in the early 2000 s continued to use IMF data, but rather than rely solely on the category of "workers' remittances," World Bank researchers constructed a more expansive definition that summed together three separate categories from the balance-of-payments accounting framework. They believed that this offered a more accurate measure of remittances volumes because it captured flows that were often misclassified by official compilers. However, as they readily admitted, this reliance on official data meant that transfers sent through informal channels were still not included in their improved measures (Ratha, 2003: I7I-72).

The researchers associated with the MIF's Remittances Program, on the other hand, tried to create a statistical measure that would capture the total volume of remittances flows, including those sent through both formal and informal channels. To this end, they adopted a measurement strategy that, they argued, generated a more accurate picture of the magnitude of remittance flows by triangulating different sources of data, including the official balance-of-payment statistics, census data, and surveys of remittance senders and recipients. (See Orozco, 2005.)

Even though they disagreed over the most appropriate techniques to measure remittance flows, once the various proponents of the R-2-D agenda came up with their own particular versions of "more accurate" statistics and measurement tools, they utilized similar sociotechnical practices to express their measures and recast the significance of remittances within development discourse. The most common of these practices was to transform their data into tables, charts, graphs, and maps demonstrating in visual form the growing importance of remittance flows.

A central indicator used to demonstrate the growing significance and importance of remittances was, unsurprisingly, 
$\$$ billions

\begin{tabular}{|c|c|c|c|c|c|c|c|c|c|}
\hline & 1990 & 1995 & 2000 & 2001 & 2002 & 2003 & $2004 \mathrm{e}$ & $2005 \mathrm{e}$ & $\begin{array}{l}\text { Change (\%) } \\
2005-2001\end{array}$ \\
\hline Developing countries & 31.2 & 57.8 & 85.6 & 96.5 & 113.4 & 142.1 & 160.4 & 166.9 & 73 \\
\hline Lower middle income & 13.9 & 30.0 & 42.6 & 47.4 & 57.3 & 72.5 & 83.5 & 88.0 & 86 \\
\hline Upper middle income & 9.1 & 14.5 & 20.0 & 22.3 & 23.0 & 27.8 & 33.0 & 33.8 & 52 \\
\hline Low income & 8.1 & 13.3 & 22.8 & 26.8 & 33.1 & 41.8 & 43.9 & 45 & 68 \\
\hline $\begin{array}{l}\text { Latin America and the } \\
\text { Caribbean }\end{array}$ & 5.8 & 13.4 & 20.1 & 24.4 & 28.1 & 34.8 & 40.7 & 42.4 & 74 \\
\hline South Asia & 5.6 & 10.0 & 17.2 & 19.2 & 24.2 & 31.1 & 31.4 & 32.0 & 67 \\
\hline $\begin{array}{l}\text { East Asia and the } \\
\text { Pacific }\end{array}$ & 3.3 & 9.7 & 16.7 & 20.1 & 27.2 & 35.8 & 40.9 & 43.1 & 114 \\
\hline $\begin{array}{l}\text { Middle East and North } \\
\text { Africa }\end{array}$ & 11.4 & 13.4 & 13.2 & 15.1 & 15.6 & 18.6 & 20.3 & 21.3 & 41 \\
\hline $\begin{array}{l}\text { Europe and Central } \\
\text { Asia }\end{array}$ & 3.2 & 8.1 & 13.4 & 13.0 & 13.3 & 15.1 & 19.4 & 19.9 & 53 \\
\hline Sub-Saharan Africa & 1.9 & 3.2 & 4.9 & 4.7 & 5.2 & 6.8 & 7.7 & 8.1 & 72 \\
\hline $\begin{array}{l}\text { World (developing \& } \\
\text { industrial) }\end{array}$ & 68.6 & 101.6 & 131.5 & 147.1 & 166.2 & 200.2 & 225.8 & 232.3 & 58 \\
\hline $\begin{array}{l}\text { Outward remittances from } \\
\text { developing countries }\end{array}$ & 6.1 & 12.5 & 12.1 & 14.3 & 18.7 & 20.2 & 24.1 & - & - \\
\hline $\begin{array}{l}\text { Outward remittances from } \\
\text { Saudi Arabia }\end{array}$ & 11.2 & 16.6 & 15.4 & 15.1 & 15.9 & 14.8 & 13.6 & - & - \\
\hline
\end{tabular}

Fig. 2.I. World Bank tabulation of remittance flows worldwide between 1990 and 2005. (Source: World Bank, 2006: 88, table 4.I.)

annual growth rates. Research published by the World Bank, for example, often included tables designed to demonstrate the continual growth of remittances over recent decades. Figure 2.I is an example of an oft-reproduced type of such a table (World Bank, 2006: 88; see also, Ratha, 2007: 2; Vargas Lundius et al., 2008: 15; Ratha, Mohapatra, and Silwal, 2009: Io). In this particular table, we are provided with a compilation of data on workers' remittances received between 1990 and 2005 by developing countries within various groupings, such as income level or regional location. For each of these groupings, statistics are provided about the quantity of remittances received for various years between I990 and 2005. The chart's final column offers an interpretation aid to those readers who may feel bedazzled by all these categories, groupings, and quantities, as it draws out the main point the table is meant to convey: that the rate of growth for workers' remittances during the period from 200 I to 2005 was spectacular, 
ranging from 4I percent in the Middle East and North Africa to a whopping II4 percent in East Asia and the Pacific.

The compilation and tabulation of remittances data have been complemented by graphs that represent visually the spectacular growth recorded over recent years. This is sometimes done for particular countries. In other cases, graphs are used to present growth trends at more-encompassing regional or global scales. Figure 2.2 shows one of these graphs for the regional grouping of Latin America and the Caribbean. In these graphical representations, the rate of growth appears nearly exponential; and this is precisely the intention of their authors. The following excerpt from the authors of the report that contains the graph in Figure 2.2 illustrates this well. These World Bank researchers, apparently writing just before the onset of the global financial crisis unleashed in 2007 , suggest that the rate of growth portrayed in their graph was likely to continue well into the future:

This figure does not give any indication of remittances flows leveling off or stabilizing. If anything, the figure indicates that there is a clear upward tendency underlying the data to the point that a simulation of the evolution of remittances under the assumption of a continuous trend would result in remittances of about US $\$ 60$ billion in 2007. While this estimate is likely to be on the high side of what one could expect, it nevertheless highlights the fact that a collapse in remittances does not seem very likely over the short run.

(Acosta, Fajnzylber, and López, 2008: 26; citation omitted)

One graphical technique that merits special treatment here is the mapping of remittances data that was carried out by the MIF for Latin America beginning in the early zooos. In collaboration with the International Fund for Agricultural Development (IFAD), the MIF would extend this coverage worldwide 


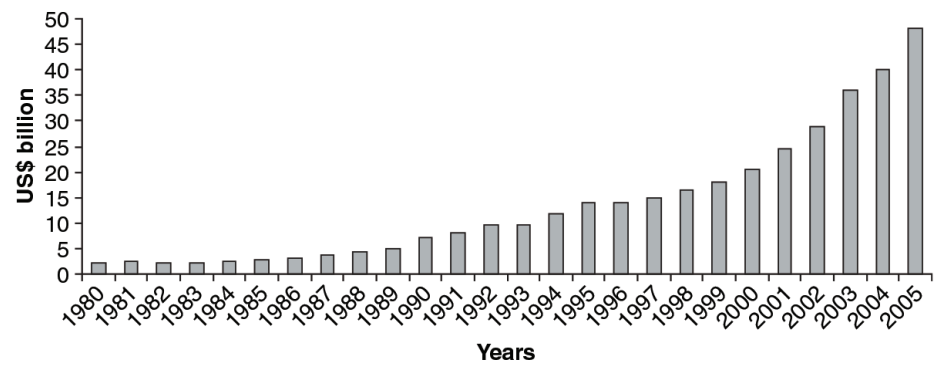

Fig. 2.2. World Bank graph showing high rates of growth in remittances to Latin America between 1980 and 2005. (Source: Acosta, Fajnzylber, and López, 2008: 26, fig. 2.4.)

beginning in 2007. In Figure 2.3 below we find a copy of the MIF map of remittances flows to the Latin American-Caribbean (LAC) region in 2008, while Figure 2.4 is a copy of the IFAD map with worldwide flows for 2006.

One of the more striking features of these maps is their rudimentary nature. They provide no detail about the actual flow of remittances; that is, we see no arrows demonstrating whence monies originate nor whither they are destined. In the case of the MIF map there is, perhaps, some rationale for this absence, since significant proportions of remittance monies for much of the region come from one single economy, that of the United States. This is particularly true for countries like Mexico and El Salvador, whence the vast majority of emigrants reside in the United States. But this pattern of migrant concentration within the United States does not hold for the entire region. Some Latin American countries receive significant remittance amounts from other parts of the world, including Europe and Japan. Migrants from Ecuador, for example, are concentrated fairly evenly between the United States and Spain (Jokisch, 2007). This more complex pattern, where the emigrants of some LAC countries tend 


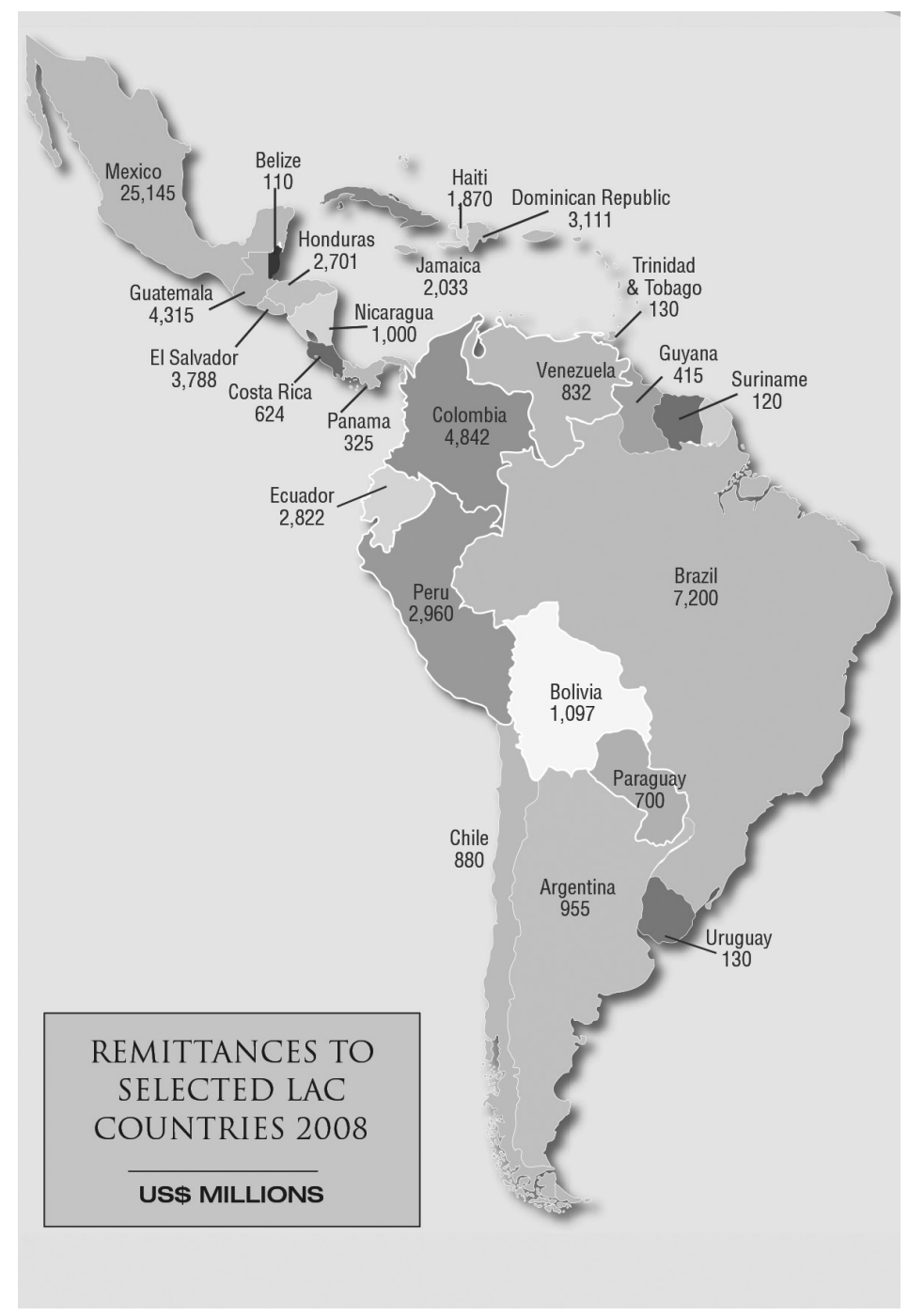

Fig. 2.3. IADB/MIF map showing remittances received across the Latin America-Caribbean region in 2008. (Source: Inter-American Development Bank/Multilateral Investment Fund, 2009: 2.) 
Worldwide remittance flows to developing countries in 2006 (US\$ million)

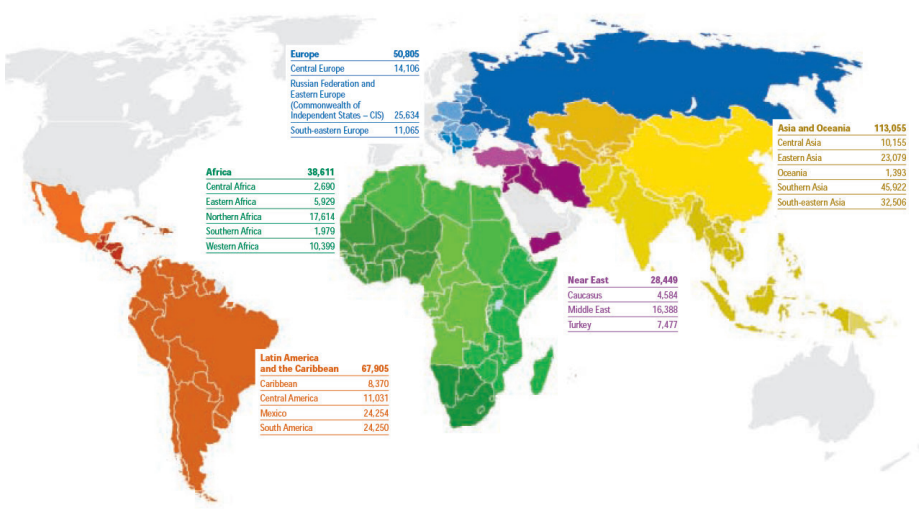

Estimated total remittances to developing countries: US $\$ 300$ billion

Fig. 2.4. IFAD map showing remittances received around the world in 2006. (Source: International Fund for Agricultural Development, 2006: 3.)

to concentrate in the United States while those of other countries are more widely spread across the globe, is not always lost on MIF researchers (MIF, 2003: 7; 2004: 9). Curiously, however, this pattern is something that gets noted in the body of MIF reports but is never translated onto their maps. ${ }^{3}$

When we look at worldwide remittance flows, purportedly captured on the IFAD remittance maps, there is of course no single concentrated site of origin for the majority of remittance monies comparable to the United States' relationship with the LAC countries. For this reason, the absence of arrows indicating origins, destinations, and directionality on the IFAD maps that claim to represent the worldwide flow of remittances may seem even more puzzling. But there is a reason for this absence. While 
specific and detailed information about origins and destinations may be of value to some interested observers, for the purposes of these maps generated by the IFAD and the MIF, rudimentary detail is sufficient. This is because these maps are meant to demonstrate, in striking visual form, one simple characteristic of remittances flows: their aggregate volume.

In addition to these efforts at documenting and presenting graphically the volume and growth rates of remittances, the promoters of the R-2-D agenda have also worked to represent remittances as a financial flow comparable to other sources of external finance, most notably foreign direct investment (FDI) and official development assistance (ODA). When these comparisons are made, remittances generally receive a favorable accounting vis-à-vis other global financial flows on two counts: overall volumes and stability. It is common to read in official reports of development institutions, for instance, statements like the following from the IFAD's 2008 report "International Migration, Remittances, and Rural Development": "Worldwide, remittances have become the second largest capital inflow to developing countries after FDI and before [ODA] ... In some countries, remittances have even surpassed the levels of FDI and ODA" (Vargas Lundius et al., 2008: 14).

Beyond this relational comparison in terms of aggregate volumes, remittances are also often compared favorably to other financial flows on the basis of their apparent stability and countercyclical nature (Ratha, 2003). The claim about the countercyclical nature of remittance flows has been widely reproduced (IAD, 2004: 4; Terry, 2005: 9-IO), although the claim is sometimes laid out in more tepid language, such as that they "may move countercyclically relative to the economic cycle of the recipient country" (World Bank, 2006: 99, my emphasis). Even with this qualification, 
this has been an extremely important claim, marking a complete about-face from policy experts' earlier portrayals of remittances as "notorious for their volatility" (Díaz-Briquets and PérezLópez, 1997: 414; see also Hernández and Bibler Coutin, 2006).

The claim about the stability and countercyclical nature of remittances flows is often supported by charts and graphs demonstrating their relation to other financial flows and representing their supposedly less violent reactions to business cycles, financial crises, and natural disasters. Figure 2.5 is an example of a graph aiming to illustrate the stability of remittances. The graph shows the slow but steady upward march of remittances at the global scale from 1990 through 2008 , with little of the fluctuation of other financial flows and a much more measured response to the effects of the global financial crisis unleashed in 2007. It also demonstrates, as development-industry officials claim, that remittances have outstripped ODA for most of this period, even if they have not yet outperformed FDI flows and have been dwarfed by portfolio-investment flows in some years.

As Figure 2.5 shows, the extraordinary rates of growth in remittance volumes registered through the mid-20oos did eventually come to an end, as a consequence of the global financial crisis. MIF figures documented a decline of 15 percent for flows to the LAC region in 2009 (MIF, 20I0). At the global scale, declines were more measured, with the World Bank estimating a worldwide fall in remittances for 2009 of just over 6 percent (Ratha, Mohapatra, and Silwal, 2009; World Bank, 20II: 17).

The technical practices identified and analyzed here have more or less successfully constructed an image of migrant remittances as a financial flow characterized by high volumes, impressive growth rates, and relative stability. Let me highlight two important issues with this particular portrayal of remittances as a financial flow. 


\section{Remittances Compared with Other Resource Flows}

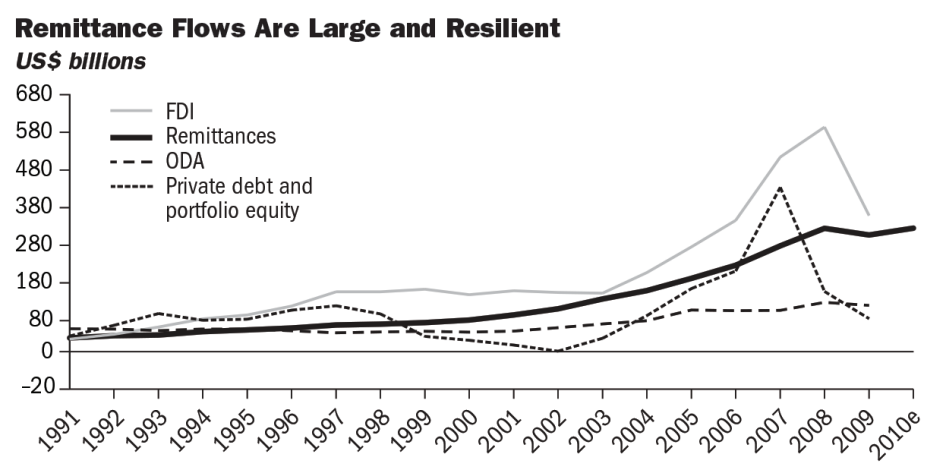

Fig. 2.5. World Bank chart comparing remittances favorably with other financial flows between I99I and 20I0. FDI, foreign direct investment; $O D A$, official development assistance. (Source: World Bank, 20II: I7.)

The first thing to note is that, built as it is on relational comparisons between remittances and other financial flows, this representation relies on historical data on the volume, growth, and stability of remittances. However, the very institutions and researchers that actively constructed this conception of remittances as a financial flow were themselves, as noted above, highly skeptical about the quality and accuracy of the data used to construct these comparisons. In an interview that I conducted with the former manager of the MIF, he pointed to these limitations, saying:

You know, I'm amused sometimes, or bemused, I guess, to read all of the data that is coming in about how fast remittances have been growing over the last ten years, when most of that growth is not actually increase; it's better reporting. They haven't been increasing 37 percent and 42 percent. I think they were, they aren't right now, but I think they were increasing 7, 8, I0, I2 percent a year.

(Interview with Donald Terry, 2009) 
Here, Terry readily admits that the spectacular growth rates seen in remittances data compiled by his and other international agencies were largely the result of better reporting - the widespread use of new data-collection and data-measurement techniques. That is, these growth rates were largely the result of changing accounting practices: with greater focus and attention on data-collection procedures came higher volumes of recorded remittances. In this sense, the spectacular growth rates identified in the early-to-mid-20oos were a fiction, the result of comparing apples with oranges. But these headline-grabbing statistics were useful for their shock value, as they brought remittances to the attention of government officials, development agencies, and financial institutions.

The second issue to note about the construction of remittances as a financial flow is related to the fact that, as we will see in the next chapter, this representation of remittances as a large, growing, and relatively stable financial flow laid the foundation for a set of market-based solutions promising to "leverage" remittances for development purposes. Thus, despite the fact that the financial crisis unleashed in 2007 undermined the characterization of remittances as a countercyclical financial flow relatively immune to the vagaries of financial crises, recessions, and business cycles, this particular representation of remittances was far too important for the promoters of the R-2-D agenda to let it fall so easily.

A 2009 MIF report lamented that "remittances to the LAC region will decrease in 2009, marking the first downturn since the Inter-American Development Bank began tracking these flows in the year 2000" (MIF, 2009: 3). However, the report rehabilitated the notion that remittances were relatively stable to conclude on the following optimistic note: "Despite the decline 
expected in 2009, remittances will remain a far more stable source of foreign currency than other financial flows, while maintaining millions of people above the poverty line" (MIF, 2009: 5, my emphasis). As a remittances specialist at the IADB suggests in the following lengthy quote, migrants' ability and willingness to adapt is the key reason for this apparently greater stability:

The defining characteristic of remittances is that they are seen as a family obligation. Senders are more likely to cut back on their own consumption than to reduce the amount of money they send to their families. Unlike speculative flows or foreign investment, therefore, profit motives do not drive remittance levels. As a result, changing economic or political risks and natural disasters will not negatively impact the decision to send. In fact, remittances typically increase during such periods, providing recipient families and developing economies with a cushion in troubled times.

The current [2008] financial crisis, however, presents a new combination of factors, as both senders and recipients are confronted by similar forces simultaneously... This is causing concern that we may be testing the limits of remittance counter-cyclicality.

How remittance flows will be affected by the financial crisis is wholly dependent on the ability of migrant workers to find strategies to adapt. Surveys and focus groups conducted for the [IADB] and by the IAD (Inter-American Dialogue) suggest that immigrants are working longer hours to compensate for lower wages, switching sectors after job loss, responding to labor demand and/or local immigration enforcement by moving from one state to another, and even tapping into their saving to maintain remittance levels. Immigrants have proven to be more adaptable than other parts of the labor force, and have been able to maintain remittance flows despite the current 8 percent Hispanic unemployment and job losses in traditionally important sectors such as construction. Current evidence suggests that we are not yet testing the boundaries of this ability to adapt.

(Meins, quoted in Migrant Remittances, 2008: 8) 
This revealing statement hints at the human aspects of migration so often obscured when remittances are aggregated into a financial flow. It reminds us that if remittances have maintained their relatively stable and countercyclical nature even in the face of an increasingly adverse political and economic climate, this results from ever-deepening levels of migrant (self-)exploitation. But the painful toll migrants experience in their efforts to keep the remittance monies flowing back to their homeland is not the focus of the policy experts behind the R-2-D agenda: their main concern is to show that migrants' apparently limitless capacity to "adapt" to deteriorating conditions confirms this financial flow's relatively stable and countercyclical nature.

The discursive and visual representations of remittances analyzed here were not sufficient on their own to transform remittances into a "development tool." The advocates of the R-2-D agenda had to take their new representation of remittances as a financial flow into the world, touting and diffusing it amongst public-opinion leaders, government officials, and financialindustry players in an attempt to link this representation to concrete changes in policy and practice. Before we turn in the next chapter to an analysis of the market-based policy interventions flowing from the representation of remittances as a financial flow, the following section analyzes the political practices and power dynamics involved in the diffusion and transfer of new remittance-measurement techniques. I focus on the Latin American region and look at how MIF officials used forms of soft power-including both offering grant funding to cooperating institutions and smearing the reputations of less cooperative ones- to induce governments and central banks in the region to improve their official remittances data. 
MEDIA PRESSURE AND GRANT FUNDING:

THE SOFT POWER BEHIND REMITTANCE-STATISTICS

IMPROVEMENTS IN LATIN AMERICA

In interviews with staff at MIF and IFAD, they told a consistent story about how their maps of remittance flows had successfully produced two primary effects: (I) they captured the attention of high-ranking officials within financial and development institutions, and (2) they helped bring pressure to bear on national officials responsible for gathering and reporting data on remittance flows.

Donald Terry, the manager of the MIF from its beginnings until his retirement in 2008 , described the work of mapping remittances flows as the most important thing that the MIF Remittances Program had done on the issue. Other staffers within the MIF and IFAD concurred with Terry about the central importance of their mapping work. Beyond simply raising awareness and elevating the visibility of remittances within banking institutions and development circles, these maps and the surveys they were built from served to bring pressure on central banks across the LAC region to improve their datacollection practices and the official statistics they reported. One MIF staffer described to me how, when they first started looking at the official statistics, they realized that these could say nothing useful about remittances, even though other financial flows such as foreign direct investment were reported with seemingly exact precision (Interview with MIF staffer, 2009). Prompted by this recognition of the severe limitations of official statistics on remittances, the MIF program then commissioned a series of surveys of remittance senders in the United States and recipients throughout Latin America in order to generate 
its own more accurate statistics. Alluding to both the initial motivation for these surveys and their eventual impact, Donald Terry told me:

I knew we had struck something of not just interest, but importance, when we started to get some pushback from central banks and the rest because we were basically willing to say, "Your numbers aren't off . . . by Io, or 15, or 20 percent"-if that's all it was, I wouldn't have been that interested in doing these surveys- - "you're off by 300 , or 400 , or 500 percent. You have no idea of how much money is coming back in."

(Interview with Donald Terry, 2009)

Another former MIF staffer described in detail how the MIF surveys and maps were put to use in pressuring national officials to improve their official statistics. He mentioned that despite the large discrepancy between their estimates and the official statistics MIF staffers initially found little traction when they communicated directly with central-bank officials. They confronted this official indifference by organizing public events in particular countries, releasing their own estimates to the national press, and trying to bring pressure on central-bank officials to improve their collection methods and official estimates. This national media coverage would often draw the attention of government officials outside the central bank and lead to rather immediate effects; upon publication of the MIF surveys and maps, centralbank officials who had initially rebuffed their overtures would contact MIF staffers to inquire about the discrepancies. Inevitably this would lead the central bankers to look into their own estimating procedures, recognize their ad-hoc nature, and come to accept the need to improve their estimates. This staffer would describe this relationship not as conflictual but as a kind of 
"constructive collaboration"-although central bankers initially resisted, they went through a process that went from surprise, to justification, and then finally led them to collaboration (Interview with former MIF staffer, 2009).

Thus, employing the bully pulpit afforded to them as representatives of a relatively reputable multilateral financial institution, MIF officials used media outlets to publicly challenge the veracity of the remittances data coming out of national institutions. As the process of surprise, justification, and collaboration ran its course in the individual countries across Latin America, the MIF staffers found success in convincing central-bank officials to pursue improvements in their collection methods and data quality. This was confirmed during my interview with Donald Terry, when he explained that: "The map that the $[\mathrm{MIF}]$ now puts out each year-for the most part now, those are the official numbers of the central banks; there's still a couple of central banks that aren't doing it. But essentially, by doing those surveys, by getting a sense of how much money was being sent-that sort-of forced the government officials to acknowledge that" (Interview with Donald Terry, 2009).

The use of national media to publicly challenge the legitimacy of the central bankers' statistics was not the only form of soft power the MIF staffers used to ensure national officials' collaboration with their regional project. The MIF program also used its grant funding to bring the LAC central bankers on board as collaborators. This is most clearly seen in the 2005 IADB/MIF grant made to the Latin American Association of Central Banks (CEMLA) to develop a coordinated strategy to improve data-collection procedures across the continent.

While the MIF Remittances Program's efforts appear to have been successful at inducing LAC central-bank officials to modify their measurement techniques, this process of change 
does not appear to have been one of either smooth collaboration or simple imposition. A closer examination of the outcome of the MIF/CEMLA grant project helps to illustrate the power dynamics involved in these efforts to improve the accuracy of remittance statistics across the region.

During a "launching seminar" for the MIF/CEMLA project held in Mexico City in 2005, the MIF consultant Manuel Orozco presented a paper entitled "Conceptual Considerations, Empirical Challenges, and Solutions in Measuring Remittances." In that paper, Orozco recommended a survey-based method for measuring remittances (Orozco, 2005). The proposed method would draw from three sources of data, including U.S. census data, random nationwide migrant surveys to determine the percentage of migrants who remit money, and data from moneytransfer companies on the "mode, median and average amount sent" (Orozco, 2005: 24). The information culled from these data sources would then be inserted into a relatively simple formula, whereby the total volume of remittances could be determined by multiplying (I) the total number of migrants; (2) the percentage of migrants that remits; and (3) the average amount remitted. Such a formula, according to Orozco (2005: 24), promised to "improve the predictive impact of remittances volumes."

My intention here is not to ponder the strengths and/ or limitations of such an estimating formula. The more modest objective is to point out that this proposed measurement technique did not meet with the full-scale approval of the LAC central banks. CEMLA staffers working on the MIF grant to improve the remittance statistics compiled by Latin American central banks preferred a direct reporting method that would rely on information provided regularly by financial institutions on the remittances payments they process. A major product emerging from 
the MIF/CEMLA grant project was supposed to be a "Manual on Best Practices for the Compilation of International Remittances." The preliminary version of this best-practice manual did not embrace the estimating techniques favored by Orozco. Instead, it suggested that "the best compilation strategy is for central banks to focus on, and obtain reports from, companies that are directly engaged in the remittance process themselves, such as nonbank [money-transfer companies] and individual banks transmitting remittances on their own account" (CEMLA, 2006: 35).

These different estimation methods could have important effects in terms of the representation of remittance flows. The direct reporting method advocated in the CEMLA manual, while potentially including a significant amount of nonremittance cross-border transfers, would likely capture more of the fluctuations in total remittances than the type of survey-based estimates advocated by the MIF. Unless their surveys of remittance senders and receivers are continuously updated, surveybased estimation techniques use a static coefficient of per-capita remittances sent by migrants. With the use of such a technique, it is really little wonder that remittance data show these flows to be growing and countercyclical-this type of formula necessarily leads to remittance-volume estimates that grow in a linear relationship with the size of the migrant population. The estimates of different organizations will differ as a result of the sources of data used to construct their "propensity to remit" coefficient. However, all estimates using such a technique will grow in lockstep with a rising population of migrants and remitters, thus contributing to the representation of remittances as large, growing, and countercyclical.

The disagreements between the central bankers and the MIF officials are probably driven as much by their differential access to 
various sources of data as by their perceptions of the accuracy of either of these methods. For officials within the Latin American central banks the use of data sources from within their own countries is likely both preferable and more practical than collecting data from sources in the United States. This is especially the case if these officials can use the power of the state to require financial institutions operating within their national territory to directly report information about remittances receipts.

In sum, while the Latin American central bankers may have conceded to the assertion of the MIF program and its expert consultants that their official statistics were less than precise, these bankers were apparently not willing to grant the international organization the power to impose its preferred technique for remedying these inaccuracies. These divisions were rendered partly moot when the proponents of the R-2-D agenda successfully incorporated new remittances definitions and measures within revisions of the IMF's balance-of-payments framework in 2009 (IMF, 2009a). However, even with this new international measurement regime it would appear that the debate between direct reporting and survey-based estimates has not been fully resolved; a guidebook published by the IMF explaining the new definitions and reporting procedures could only go so far as to advise governments to "develop data compilation strategies based on the needs, constraints, and capabilities of their own countries" (IMF, 2oogb: 3).

\section{CONCLUSIONS}

This chapter began by examining the technical practices deployed by actors within international development agencies to construct remittances as a financial flow. These included 
the elaboration of more accurate statistics and measurement tools, as well as the transformation of the improved data developed through these new tools into tables, charts and graphs that would forcefully demonstrate in visual form the growing importance of remittance flows. The chapter also illustrated the political dynamics involved as officials associated with the MIF and IFAD used various forms of soft power to spread their preferred data-collection techniques and representations of remittances as a financial flow across Latin America and the world.

The focus of this chapter has thus been on the discursive and technical construction of remittances as a financial flow of great importance for development in the global South and on the efforts of development-industry officials to spread particular measurement techniques that promised to improve the statistical data underlying such a construction. In creating and mobilizing these data-collection techniques and visual representations the purveyors of the R-2-D agenda have rather successfully spread across the world the view that the relatively small amounts of money transnational migrants send to family and friends living back in the homeland constituted a large, rapidly growing, and relatively stable cross-border financial flow. But in and of itself this examination tells us little about how the proponents of the R-2-D agenda articulated the connection between remittances and development. How, exactly, did they make the link between their representations of remittances as a financial flow and development processes in the global South? The representation of remittances as a financial flow was particularly amenable to market-based policy interventions aimed at further incorporating migrants and their monies within financial institutions and 
markets. And this is precisely the type of policy intervention the purveyors of the R-2-D agenda designed, promoted, and implemented as they sought to turn remittances into a "development tool." In the following chapter I analyze the content and rationale of these market-based solutions, and the governmental work that made them possible. 